УДК 37.01

\title{
ЦЕННОСТНАЯ ОРИЕНТАЦИЯ ВОСПИТАНИЯ ОБУЧАЮЩИХСЯ НА ОСНОВЕ ТЕХНИЧЕСКОГО ТВОРЧЕСТВА
}

\author{
Павлов Дмитрий Игоревич \\ зам. директора по ВР \\ ЯИВТ (филиал) ФГБОУ ВО «СГУВТ» \\ аспирант ПИ \\ ФГАОУ ВО «СВФУ им. М.К. Аммосова»
}

Аннотация: В данной статье рассматривается проблема изменения традиционных ценностных ориентиров в молодежной среде. Автором представлен потенциал объединения технического творчества как педагогической формы в личностно-профессиональном становлении обучающихся на примере секции по судомоделированию в образовательной организации.

Ключевые слова: ценностная ориентация воспитания, техническое творчество, преемственность поколений, судомоделирование, молодежная среда.

\section{VALUE ORIENTATION OF EDUCATING STUDENTS ON THE BASIS OF TECHNICAL CREATIVITY}

\section{Pavlov Dmitry Igorevich}

\begin{abstract}
This article discusses the problem of changing traditional value orientations in the youth environment. The author presents the potential of associations of technical creativity as a pedagogical form in the personal and professional development of students on the example of the ship modeling section in an educational organization.
\end{abstract}

Key words: value orientation of education, technical creativity, succession of generations, ship modeling, youth environment.

Вопросы по формированию ценностей у молодого поколения во все времена вызывали бурное обсуждение и разность мнений в обществе. 


\section{МОДЕРНИЗАЦИЯ СОВРЕМЕННОГО ОБРАЗОВАНИЯ: АНАЛИЗ ОПЬТА И ТЕНДЕНЦИЙ}

Однако не замечать текущую сложную ситуацию происходящих изменений в мировоззрении, в ценностном отношении молодежи невозможно. Деградация профессиональных ценностей в молодежной среде, происходящая в благоприятных для разложения условиях кризиса общества и его фундаментальных институтов социализации, требует от научного сообщества незамедлительного переосмысления в выборе подходов и определения новых ориентиров для системы российского образования, а также других государственных механизмов, связанных с воспитанием молодого поколения.

События уходящих дней открывают перед нами страшную картину подмены традиционных коллективистских духовных ценностей на корыстноиндивидуальные. Такая переориентация вызывает у нас опасения о будущем российской промышленности, транспортных систем и других профессиональных сфер по жизнеобеспечению населения, где нравственная основа является фундаментом безопасности для общества. Обновление кадров на любом предприятии является априори естественным процессом, и будущее этих предприятий во многом зависит от заинтересованности, мотивации, готовности к качественной профессиональной деятельности молодежи. Мы должны понимать, что специалист, получивший только теоретические и практические навыки по средствам обучения, но не имеющий нравственных основ, не способен выполнять государственно-важные задачи, подразумевающие понимание специалистом ответственности за общее дело. Отсутствие должного внимания к представленной проблематике может привести к переориентации молодого поколения: предпочтение ими западной культуры в ущерб отечественной, подмене веками сформированных отечественных ценностей и идеалов, определяющих социальную идентичность российского общества.

На фоне представленных изменений механизмов социального наследования современные образовательные организации призваны стать ключевым механизмом в процессе передачи знаний, ценностей, мироощущений и традиций благодаря преемственности поколений, основанной на многовековой истории, организации дисциплины, регламентированности поведения воспитанников, преподавателей, тьюторов, воспитателей, установленными правилами внутреннего распорядка, правильной подборки конкретных мероприятий, охватывающих все возможные направления образовательно-воспитательной деятельности [5, c. 148$]$. 


\section{МОДЕРНИЗАЦИЯ СОВРЕМЕННОГО ОБРАЗОВАНИЯ: АНАЛИЗ ОПЬТА И ТЕНДЕНЦИЙ}

Последние принятые распоряжения Правительства Российской Федерации от 12.11.2020 года № 2945-р «Об утверждении мероприятий по реализации в 2021-2025 годах Стратегии развития воспитания в Российской Федерации на период до 2025 года» и изменения, внесенные в Федеральный закон «Об образовании в Российской Федерации» 8 декабря 2020 года открывают перед образовательными организациями широкое поле возможностей в активизации деятельности по воспитанию молодежи/будущих специалистов путем непосредственного воздействия на них через образовательно-воспитательный процесс.

Для подробного рассмотрения особенностей формирования ценностной ориентации обучающихся мы использовали методологические положения, разработанные такими отечественными исследователями, как АбульхановойСлавской К.А., Ананьевым Б.Г., Брушлинским А.В., Леонтьевым А.Н., Мясищевым В. Н., Петровским А.В., Рубинштейном С.Л., Кирьяковой А.В., Ольховой Т.А., Эксакусто Т.В., Дугановой Ю.К. Стахневой Т.А., Борытко Н.М., Тырсикова Д.В. и др. Анализ источников позволил выявить взаимосвязь между субъектностью обучающихся и профессиональными ценностными ориентациями. Под профессиональными ценностными ориентациями мы понимаем систему устойчивых отношений личности к будущей профессиональной деятельности, являющихся смыслообразующим компонентом, определяющим ее личностное и социальное значения. Таким образом, формирование профессиональных ценностных ориентаций у обучающихся подразумевает создание благоприятных педагогических условий в образовательной организации. В качестве некоторых из таких условий мы выделяем ориентацию образовательно-воспитательного процесса на личностно-профессиональное становление обучающихся, субьектсубьектное взаимодействие воспитанников и педагогов, предполагающее совместную творческую и техническую деятельность в рамках образовательного пространства.

В нашей статье мы не даем исчерпывающий ответ на вопросы решения всех проблем, связанных с изменениями механизмов профессионального наследования в молодежной среде, а предлагаем одно из направлений совместной творческой и технической деятельности воспитанников и преподавательского коллектива в качестве педагогической формы, позволяющей создавать в образовательной организации необходимые условия на примере Якутского института водного транспорта (филиал) Федерального 


\section{МОДЕРНИЗАЦИЯ СОВРЕМЕННОГО ОБРАЗОВАНИЯ: АНАЛИЗ ОПЫТА И ТЕНДЕНЦИЙ}

государственного бюджетного образовательного учреждения «Сибирский государственный университет водного транспорта». В данной образовательной организации ведется подготовка кадров для транспортной отрасли (речной транспорт) Республики Саха (Якутия) по программа высшего и среднего-профессионального образования.

В целях качественной подготовки специалистов в образовательной организации уделяется значительное внимание ценностной ориентации воспитания обучающихся, формирование которой производится на основе комплексной образовательно-воспитательной работы, через участие обучающихся в мероприятиях и дополнительных техническо-творческих секциях по направлениям. Так, например, обучающиеся института в рамках воспитательной деятельности расширяют полученные при обучении теоретические и практические навыки на занятиях по судомоделированию, выступающих одной из форм популяризации среди обучающихся знаний основ речного дела, судостроения, технических особенностей эксплуатации судна, способствующей привитию у обучающихся интереса к флотским традициям. Параллельно с процессом моделирования для обучающихся проводятся классные часы, посвященные истории становления российского флота, великим адмиралам, подвигам русских моряков, историям военных судов и др. На занятиях курсанты изготовляют судовые модели как стендового класса, так и плавающего. Разработка моделей и их отдельных частей основывается на командной работе всех участников процесса, в состав входят опытные руководители из числа преподавателей, обучающиеся, возможно участие других заинтересованных лиц. При изготовлении моделей особое внимание уделяется разработке различных судовых систем, оборудования, боевых орудий, поддающихся практической иллюстрации на макете (якорное устройство, стопоры, шпили и брашпили, якорные клюзы, лебедки, кнехты, швартовые клюзы, киповые планки, буксирные гаки и арки, раструбы, грибки, пожарные краны со шлангами, ватерлиния, рулевое устройство, грузовые стрелы и краны, спасательные плоты и круги, шлюпбалки). В том случае, если модель готовится плавающего класса, то при разработке проекта уточняются предположительные судоходные качества: остойчивость, осадка, скорость предположительного хода, грузовые характеристики и др.

Важной составляющей занятий по судомоделированию является процесс проверки модели и его запуск, так как экспериментальная часть 


\section{МОДЕРНИЗАЦИЯ СОВРЕМЕННОГО ОБРАЗОВАНИЯ: АНАЛИЗ ОПЫТА И ТЕНДЕНЦИЙ}

позволяет определить достоинства и недостатки проекта, оценить конструкторскую деятельность обучающихся. Лучшие модели по итогам запуска представляются на различных городских, республиканских соревнованиях по техническому творчеству молодежи и далее передаются для хранения в Центр исторического наследия речников Ленского бассейна, где числится более 30 различных моделей судов, изготовленных обучающимися разных лет, начиная с 1970 года. Итоговая экспериментальная часть проводится с обязательным приглашением экспертов в области судомоделирования из числа городских и республиканских общественных объединений, занимающихся парусным спортом, судомоделированием или техническим творчеством. Подробное описание поэтапного технологического процесса разработки модели судна представлено на рис. 1.

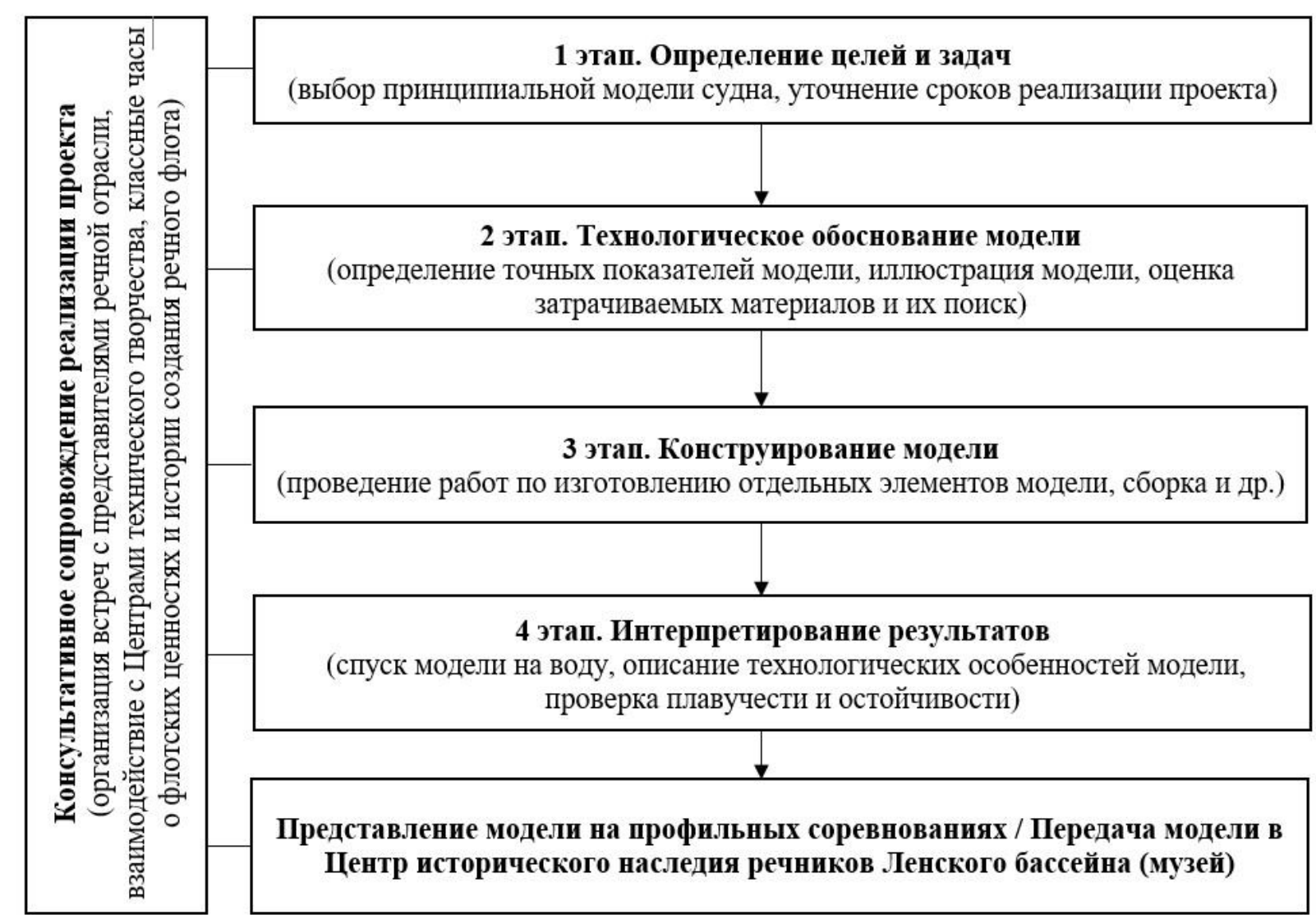

\section{Рис. 1. Этапы технологического процесса по разработке модели судна}

В целях оказания необходимой консультативно-технологической поддержки при произведении моделей институт многие годы взаимодействует с общественной организацией «Пятнадцатилетний капитан». При совместной 


\section{МОДЕРНИЗАЦИЯ СОВРЕМЕННОГО ОБРАЗОВАНИЯ: АНАЛИЗ ОПЬТА И ТЕНДЕНЦИЙ}

деятельности на базе секции по судомоделированию института в период с 2018 по 2020 годы было построено 10 моделей парусных яхт типа «Оптимист» (швертбот), которые в настоящее время успешно используются при проведении парусных регат. В 2021 году были произведены ремонтные работы двухместной яхты для подросткового экипажа типа «Кадет». В 2022 году планируется сборка 10 кит-наборов весельных лодок типа «Лещ».

Вовлечение курсантов института в деятельность секции по судомоделированию дополняет общий курс образовательно-воспитательных мероприятий, проводимых в институте, позволяет прививать обучающимся любовь к труду, избранной профессии, воспитывать их на основах коллективизма, прививать флотские традиции, ценностные ориентиры, связанные с профессиональным долгом, личной ответственностью за коллективный результат, формировать вспомогательные профессиональные навыки необходимые в будущей профессиональной деятельности. Непосредственное участие педагогов в совместной деятельности с обучающимися выступает существенным стимулом для личностного развития обучающихся, создает атмосферу товарищества, повышает уровень инициативы обучающихся в творческой и технической деятельности.

\section{Список литературы}

1. Брыкова Л.В. Теория и технология технического творчества в профессиональном техническом образовании // Молодежь и научнотехнический прогресс. - 2017. - С. 27-30.

2. Ветрова О.Г. Техническое творчество как важная часть учебного процесса в подготовке специалистов технического профиля // Современное общество, образование и наука. - 2013. - С. 38-39.

3. Захарова А.К. Детское техническое творчество - основа технического прогресса общества // Техническое творчество молодежи. 2021. - C. 4-8.

4. Николаева А.Д. Педагогический потенциал экологических традиций как ресурс формирования личности (на примере Якутии) // Общество: социология, психология, педагогика. - 2017. - С. 99-102.

5. Павлов Д.И. Преемственность поколений как составляющая уклада жизни образовательной организации командного типа // Профессиональное самоопределение: новые реалии, подходы, технологии. - 2020. - С .147-150. 
6. Полухина О.П. Формирование у будущего специалиста устойчивой профессионально-личностной позиции как основы процесса самореализации // Материалы XX Отчетной научно-практической конференции профессорскопреподавательского состава. - 2017. - С. 220-224.

7. Романов Н.Н. Развитие технического творчества учащихся в условиях кружка по судомоделированию // Научно-методический электронный журнал «Концепт». - 2017. - С. 168-170.

() Д.И. Павлов, 2021 